\title{
Editorial
}

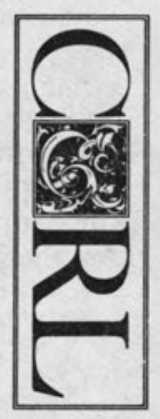

\section{Developing a Research Perspective}

Simply put, the time has come to acknowledge that the capacities of recently developed technologies are such that important aspects of teaching and research now can be fundamentally transformed and improved for the benefit of individual students, scholars, and society. Libraries have a unique and inescapable role to play in this transformation. They need only to find the way.

Council on Library Resources

To help celebrate the tenth anniversary of College \& Research Libraries, then-editor Maurice F. Tauber prepared and published "Investigations and Research Projects in the Field of College Libraries" (October 1950). The article reviews studies that were conducted from 1940 to 1950 . Tauber's purpose was to find out what had been learned about college library problems and what was being done to improve services and programs to meet more effectively the demands being placed on the college library. Appearing in the same issue was Dorothy Ethlyn Cole's "Areas for Research and Investigation in the College Library Field." Her survey results were based on the responses of sixty-three librarians from the College Libraries Section of ACRL.

Almost forty years later another collective effort is underway to suggest the types of research issues that need to be addressed. This editorial, a follow-up to the May editorial, "What Is Research?" will show evidence of our " profession's progress toward developing a set of important research questions."

Is there a research agenda for academic libraries? The answer is clearly no. On the other hand, an implicit consensus has developed that the time has arrived to say where we are and where we want to go.

Paul Metz suggests that "small issues have been reexamined in exacting methodological detail" but work on large issues is "merely anecdotal or hortatory." In "Thinking Big: A Commentary on the Research Agenda in Academic Librarianship" (CERL, September 1985), Metz exhorts us to examine large issues-library costs, use, collections, users, and higher education.

In 1987, the Association of Research Libraries distributed a list of topics and questions for the purpose of encouraging related research activity. This short list is reprinted in "Research Notes" on page 467.

In its 1985 annual report, the Council on Library Resources calls for an expanded research program. The program is not articulated in the form of a research agenda but is outlined through the listing of a series of question topics organized within three areas: 


\section{INFORMATION CHARACTERISTICS}

- What is the relationship between the characteristics of documents (format, length, language, age, etc.) and their usefulness?

- Are format requirements fundamentally different for various disciplines or kinds of use?

- Do large files of machine-readable information and new processing capabilities affect the substance as well as the methodology of research?

- Are there useful ways to assess the quality of information and information service?

- What is the relationship between knowledge of the existence of information and actual use?

\section{USER REQUIREMENTS}

- How do information needs vary by discipline?

- How parochial is the information-using community?

- In the complex information environment that is anticipated, what is the future role of libraries, especially in relationship to teaching?

\section{THE STRUCTURE OF INFORMATION SYSTEMS}

Examples of topics include:

- The organization of information activities in research universities

- Collection management

- Multi-institutional operations

- Problems of technology

- Opportunities for technology

It may be assumed that the preparation of a research agenda is a monumental task, perhaps an impractical task, or politically an unwise, unwarranted, or unnecessary intrusion into the dynamics of the library research marketplace. In spite of the barriers, organizations and individuals are trying to say something about what needs to be done, even if this something is not all-inclusive.

Mary Jo Lynch, director of the ALA Office for Research, is editing a book with the working title of Academic Libraries for the Year 2000: A Research Perspective, to be published in the ACRL Publications in Librarianship series. More than ten experts are contributing to this book. The book will summarize what has been done and what needs to be done in nine chapters on the following subjects: (1) management theory and organizational structure; (2) budgeting, costing, and planning; (3) personnel; (4) collection management, development, and preservation; (5) bibliographic organization/control; (6) use studies; (7) access services; (8) instructional services; and (9) technology. Publication is expected in late 1989.

Divisional research units throughout ALA are currently engaged in analyzing ALA's "Planning Document: Goals and Strategies" to determine how research can play a role in furthering the activities and advancing the goals of the association. The ALA Committee on Research has prepared an extensive list of research topics and has been coordinating the preparation of this list with divisional units.

Another important document is the "U.S. Library Statistics Report," released in July 1988 by the Library Administration and Management Association, Statistics Section, National Data Collection and Use Committee. The collection of statistics is a vital function for both the association and its divisions. The recommendation in this report to establish a new ALA committee on statistics deserves serious consideration.

Fundamental transformations will make our professional lives more uncertain and more interesting. The publication of research questions may help us to focus our attention on the most important issues facing academic libraries. In turn, we may discover the "zeal for research," as Burton Clark notes in The Academic Life: Small Worlds, Different Worlds, a life that acknowledges "the intrinsic rewards of critical thought and inquiry."

\section{CHARLES MARTELL}




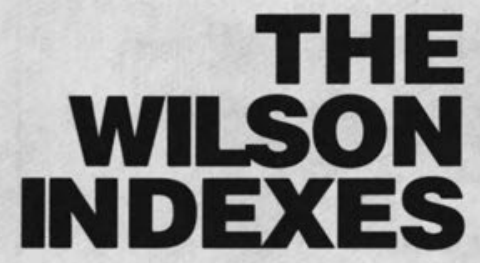

When You Need an Answer Fast and it Has to be Right Offering broad coverage, unparalleled accuracy, and unmatched currency, the Wilson Indexes are your key to important literature in business and law, science and technology, art, education, the humanities, the social sciences, and general reference.

Now you can search these renowned indexes in print, online, on CD-ROM, and with patron-accessible software.

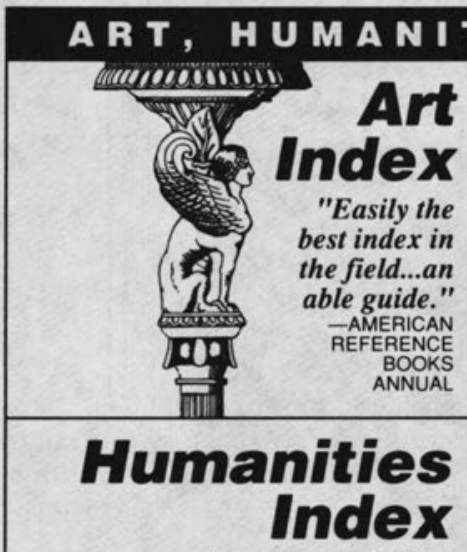

"Recommended for virtually all libraries."

-AMERICAN REFERENCE BOOKS ANNUAL

A single-alphabet, author-subject index to 230 domestic and foreign museum bulletins, periodicals, and yearbooks utilized by researchers, artists, architects, designers, collectors and others needing information about the art world, Art Index covers: - Archaeology - Architecture - Art History - City Planning - Computer Applications \& Computer Graphics - Crafts - Film - Folk Art • Graphic Arts - Industrial Design - Interior Design - Landscape Architecture - Museology • Painting - Photography - Sculpture - Television - Textiles • Video.

\section{Availability}

In Print: Four quarterly issues; annual cumulative volume. Retrospective coverage from 1929 to date; sold on the service basis (periodical budget).

Online \& CD-ROM: Coverage from 9/84. CD-ROM annual subscription $\$ 1,495$.

An invaluable research tool for students, teachers, researchers, and librarians, Humanities Index provides thorough, accurate indexing of 293 English-language periodicals in such disciplines as: - Art - Archaeology \& Classical Studies - Area Studies - Dance - Drama - Film • Folklore - History - Journalism \& Communications - Language $\cdot$ Literature $\cdot$ Music $\cdot$ Performing Arts - Philosophy $\cdot$ Religion \& Theology.

\section{Availability}

In Print: Four quarterly issues: annual cumulative volume. Retrospective coverage from 1907 to date (1907-1965 subscription: \$85 U.S. and Canada. \$95 other countries as International Index, 1965-1974 as Social Sciences \& Humanities Index); sold on the service basis (periodical budget).

Online \& CD-ROM: Coverage from 2/84. CD-ROM annual subscription \$1,295

\section{Social Sciences Index}

"An indispensable tool for access to the periodical literature of the social sciences." -AMERICAN REFERENCE BOOKS ANNUAL

Broad in scope and comprehensive in coverage, Social Sciences Index offers complete, accurate, and timely coverage of 353 English-language periodicals in such areas of the social sciences as: • Anthropology - Area Studies $\cdot$ Community Health \& Medical Care $\cdot$ Economics - Ethnic Studies • Geography • International Relations - Law $\cdot$ Criminology $\cdot$ Minority Studies $\cdot$ Planning \& Public Administration - Police Science \& Corrections - Policy Sciences • Political Science

- Psychiatry $\cdot$ Psychology $\cdot$ Social Work $\&$ Public Welfare $\cdot$ Sociology - Urban Studies.

\section{Availability}

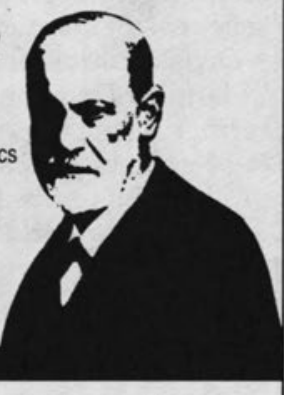

In Print: Four quarterly issues; annual cumulative volume. Retrospective coverage from 1907 to date (1907-1965 subscription: \$85 U.S. \& Canada, \$95 other countries. As International Index, 1965-1974 as Social Sciences \& Humanities Index); sold on the service basis (periodical budget).

Online \& CD-ROM: Coverage from 4/83. CD-ROM annual subscription \$1295.

H.W. WHIS company 950 University Ave., Bronx, New York 10452

\section{To Order}

or for more information on these or any of the Wilson Indexes, simply call toll-free. 1-800-367-6770

In New York State call 1-800-462-6060; in Canada, call collect 212-588-8400. 


\section{ACQUISITION PERSPECTIVES}

5. Monographs in continuation and standing orders are given special attention. Your first volume required and all future volumes will be delivered as soon as they become available.

Write or call for details about our reliable standing order service to libraries.

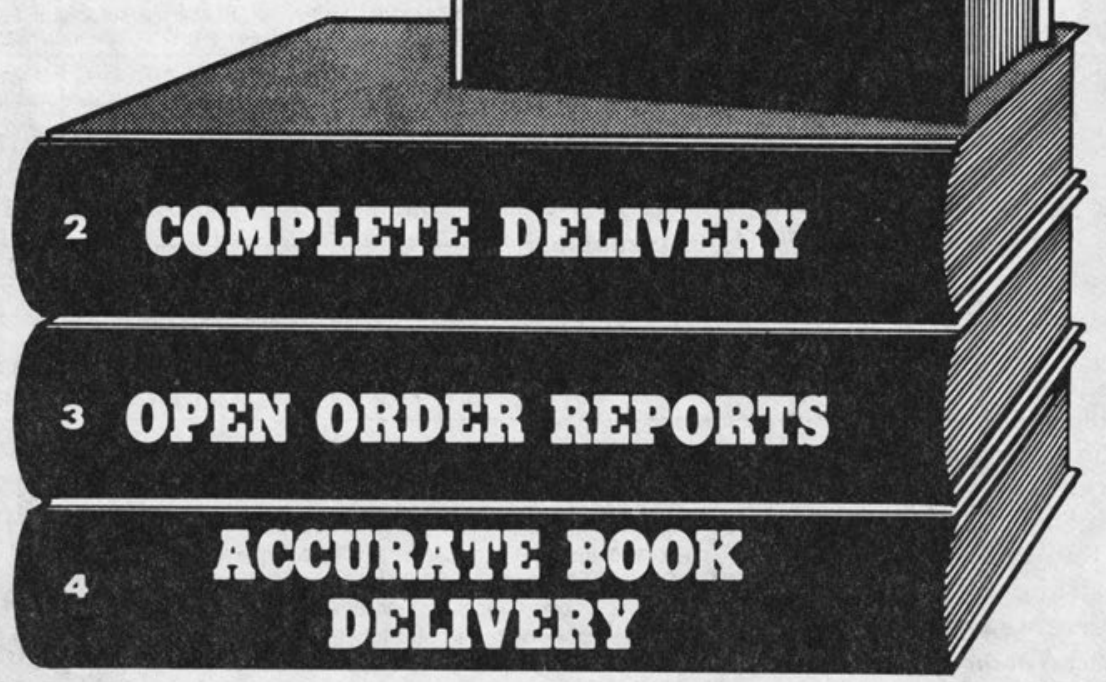

CALL TOLL-FREE TODAY

$1-800-248-1146$

In Canada \& Michigan

CALL COLLECT (517) 849-2117

OCLC Vendor No. 17397

SAN $169-3859$
5

STHDTIC OADHAS

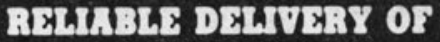

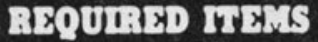

BOOK HOUSE

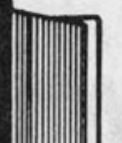

